\title{
Wspólnotowość (w) edukacji. Problem demokratycznego współistnienia
}

\author{
Community (in) education: The problem of democratic coexistence \\ Abstract
}

What I associate with the title of this article is the potential of discussions on education, which is also confirmed by attempts to combine themes selected from within it with those concerning community. I propose a precise study, which includes many pointers, and also doubts, concerning the role of education itself, mainly in the implementation of social cohesion and activities for fostering the integration of those involved in it. A specific feature of these reflections on the need to achieve community, and to confirm it in and through education, is the encouragement to engage in issues related to social (dis) integration, which is intentionally filled with aspects directly related to democracy itself.

\section{Keywords}

education, community, democracy

\section{Wprowadzenie}

Zagadnienie wiązania edukacji ze wspólnotowością wydaje się oczywiste, jednak mimo tej oczywistości odnotowujemy w związku z nim wiele kontekstów problemowych - jak należy domniemywać - sytuowanych w intensywnie zmieniającej się rzeczywistości społecznej i sposobach poszukiwania rozwiązań w obliczu stwierdzanego stanu rzeczy. Mówiąc inaczej, jeśli dostrzegamy potrzebę analiz wspólnotowego wikłania się edukacji trafiamy bez problemu na trop wybranych idei, wartości, stanów rzeczy odnoszonych do kategorii struktur społecznych i jednostek, przedstawianych jako „dobro wspólne”. Tworzy to, rzecz jasna, określoną sytuację w kwalifikowaniu społecznej funkcji edukacji i jej rzeczywistej wartości. Edukacja - oglądana z takiej perspektywy (nasycona wątpliwościami, brakiem pewności i potrzebą zmiany) nabiera określonych treści. Są wśród nich te sprzy- 
jające orientowaniu się w sprawach edukacji przedstawianej jako zainteresowanej wspieraniem indywidualnego rozwoju i bycia wspólnym dobrem. Wymaga to oczywiście oglądu naukowego, z którym demaskuje się istotę i przejawy autorytarności - przywraca sens podmiotowości, problematyzuje obecność różnych jakości edukacji - szczególnie jej egalitarności i elitarności, argumentuje zasadność oddziaływań edukacyjnych wyzwalających, promujących osobę, przy jednoczesnej negacji formacyjnego ich charakteru ${ }^{1}$.

Powstrzymując się od formułowania sądów wartościujących wskazane tendencje, powiem zbierająco, że ich faktyczne (wy)krystalizowanie się odbieram jako istotne kwestie dla ukazywania tego, jak (nie) funkcjonuje polska edukacja, narzucające jednocześnie jej znaczenie i interpretacje. Z tymi kwestiami przenika do rzeczywistości edukacyjnej demokratyzacja, decentralizacja, uspołecznienie i samorządność, swoista humanizacja stosunków społecznych. Towarzyszą temu idee pedagogiki humanistycznej, oświaty alternatywnej, pedagogiki dialogu, edukacji elastycznej, edukacji domowej. Szukając dookreśleń dla edukacji, znajdujemy: „podmiotowa”, „wartość odzyskiwana wspólnie”. Pojawia się w związku z nią postulat demokracji społecznej ${ }^{3}$. Te dopełnienia - celowo wybrane - mają być pożyteczne dla rozpoznawania zawieranej w edukacji wspólnotowości, która wyznacza kierunki przemian społecznych i edukacyjnych, przekonując do wpisanych w nie wartości - rzeczywistych lub wymyślonych. Stanowi rozstrzygnięcie w (dla) edukacji, jakim ma być indywidualne i społeczne upełnomocnienie.

Oczywiście wydawanie opinii na temat edukacji, projektowanie możliwości jej zmiany wymagają ograniczenia spektrum rozważań choćby poprzez przyjęcie określonej perspektywy czasowej. Warto przy tym mieć na uwadze także to, że w poszukiwaniu pewnych zasad porządkujących możliwe warianty wspólnotowości i edukacji ważne są dotychczasowe rezultaty analiz, zwłaszcza te zajmujące się systemem edukacji, przemianami społeczeństwa. Swoje znaczenie ma rozwijanie refleksji nad czasami ponowoczesnymi, która niewątpliwie sprzyja wyjaśnianiu zmieniającej się pragmatyki relacji międzyludzkich, podejmowaniu problemu ich przekształceń. Pozwala na akcentowanie relacyjnej strony edukacji w jej nieredukowalności i niepewności ${ }^{4}$.

${ }^{1}$ Traktują o tym m.in. prace autorskie i zbiory pod redakcją Z. Kwiecińskiego, L. Witkowskiego, B. Śliwerskiego, J. Rutkowiak, T. Lewowickiego.

2 T. Lewowicki, W stronę paradygmatu edukacji podmiotowej, „Edukacja” 1991, nr 1; Z. Kwieciński, Edukacja jako wartość odzyskiwana wspólnie (Głos w dyskusji o uspołecznieniu szkoły), „Edukacja" 1991, nr 1 .

${ }^{3}$ K. Przyszczypkowski, Edukacja dla demokracji. Strategie zmian a kompetencje obywatelskie, Toruń-Poznań 1999; Z. Kwieciński, Demokracja jako wyzwanie i zadanie edukacyjne, [w:] Z. Melosik, K. Przyszczypkowski (red.), Wychowanie obywatelskie. Studium teoretyczne, porównawcze i empiryczne, Toruń-Poznań 1998.

${ }^{4}$ Zob. L. Witkowski, Edukacja wobec sporów o (po)nowoczesność, Warszawa 1998. 
Kwestia wspólnotowości w edukacji nie pozostaje poza zasięgiem idei i wpływów społecznych, kulturowych, wymaga ciągłego rozpoznawania i rozumnego współkreowania. O jej istotności rozstrzyga niewątpliwie podejście do edukacji jako dobra wspólnego. W tym kontekście szczególnej mocy nabiera stwierdzenie B. Śliwerskiego, który pisze:

Kluczowe jest dla mnie postrzeganie edukacji jako dobra wspólnego, jako środowisk, podmiotów, instytucji czy praktyk zarządzania i uczestniczenia w demokratyzacji społeczeństwa, które jest nieustannie w drodze wychodzenia $\mathrm{z}$ wieloletnich doświadczeń faszystowskiego i bolszewickiego totalitaryzmu. Kiedy mówimy o edukacji jako dobru wspólnym, możemy traktować ją dwojako: albo akcentując „wspólność” edukacji jako dobro, albo postrzegając ją jako samo dobro, które ma stać się dla członków danego społeczeństwa czymś rzeczywistym, dostępnym, w którym i przez które każdy człowiek staje się lepszy lub przynajmniej ma możliwość takim się staćs.

Waga przytoczonego cytatu i zasygnalizowanych dotąd aspektów jest znamienna i szczególnie nimi kieruję się, spoglądając na problem wspólnotowości (w) edukacji. Podejmuję się próby rozważenia zagadnień go konstruujących, wkraczając tym samym w dobrze już rozpoznaną problematykę, która, jak się okazuje, pozostaje jednocześnie ciągle otwartą dla badań i kolejnych wniosków.

\section{Edukacja - propozycja jej odczytania}

Edukacja jest praktyką społeczną wymagającą nieustannego wysiłku, na dodatek obarczoną ryzykiem nieefektywności. Nieustannie zastanawiamy się, jak edukacja powinna wyglądać, aby spełniać jednostkowe i społeczne oczekiwania. Rozprawiamy o systemie edukacyjnym w kontekście jego zmian, które umiejscawiamy pomiędzy paradygmatem radykalno-strukturalnym a funkcjonalno-liberalnym. W projektach reform polskiej edukacji dostrzegamy przenikanie się sprzecznych ideologii: socjalistycznej (wyrównywanie szans), liberalnej (indywidualizm i decentralizacja zarządzania) oraz konserwatywnej (zwrot ku światu wartości i dyscyplinowanie systemu przez terenowe agendy rządu) ${ }^{6}$. Spotykamy ciągle wiele znaków zapytania i mnożących się wątpliwości odnośnie do instytucji edukacyjnych. Choć wydawać może się to paradoksalne, postawione przez Zbigniewa Kwiecińskiego ponad trzydzieści lat temu pytanie dotyczące edukacji „minionego już systemu” o to, „jak instytucje edukacyjne mogą przekształcić się z instrumentów uzależnienia i uprzedmio-

\footnotetext{
5 B. Śliwerski, Pedagogika (w) demokracji, „Przegląd Pedagogiczny” 2014, nr 1, s. 222.

${ }^{6}$ K. Konarzewski, O pewnej sprzeczności w projekcie reformy polskiej oświaty, „Edukacja” 1999,
} nr 1. 
towienia jednostek i grup społecznych w środki otwierania i wspomagania rozwoju jak największej liczby ludzi”7 - po dziś dzień pozostaje aktualne.

Edukacja stawiana w obliczu określonej ideologii, bywa, że poddawana jej dyktatowi, może okazać się stabilizującą status quo, powodującą zmiany progresywne, a nawet prowadzącą do dezintegracji - w wymiarze swoich społecznych i jednostkowych powinności. Towarzyszy jej jednocześnie katalog rozmaitych poczynań i relacji, wybieranych i kształtowanych przez wszystkich nim zainteresowanych w miarę chęci, potrzeb, możliwości. Stanowi też okoliczność i okazję do stawiania pytań. Pytanie o konkretne następstwa, jakie pociągnie za sobą nasycenie się przez edukację określoną ideologią, może okazać się też zagadką, której rozwiązanie wzmocni lub zburzy wiarę w magiczne właściwości samej edukacji.

Pytanie o samą edukację, jaką jest się w stanie opisać wybranymi kategoriami, ukazuje istotną i zróżnicowaną przestrzeń dociekań naukowych. Próbując ją dookreślić pod kątem pożytków poznawczych, można przyjąć, iż prowadzi ona do teoretycznego obrazu funkcjonalności edukacji wobec społeczeństwa merytokratycznego, ekspertów i demokratycznego ${ }^{8}$.

Nie jest przypadkiem, że wśród teorii wykorzystywanych dla interpretacji edukacji trafiamy na istotną przestrzeń dociekań stanowiących zbiór myśli osadzonych w nurcie krytycznym. W nim też ostatecznie edukację postrzega się jako element społecznego systemu służącego konserwacji i blokującego oczekiwania zmian, ale też jako czynnik społecznej zmiany i emancypacji (edukacja zniewala, ale wyzwolenie wymaga edukacji ${ }^{9}$ ).

Otwarcie perspektywy emancypacyjnych możliwości przypisywanych potencjalnie edukacji oznacza jednocześnie sprzeciw wobec funkcji pełnionych przez „niekrytyczną” edukację, w tym zwłaszcza opór w stosunku do procesu reprodukowania systemu społecznego powodującego ograniczenia dla rozwoju jednostek i grup społecznych. Jest to opór przeciwko pedagogice technologicznej, przeciw „represjonowaniu” i „wymazywaniu” indywidualnych tożsamości, przekształcaniu uczniów w posłuszne przedmioty, zastąpieniu spontaniczności przez wydajność i produktywność stosownie do potrzeb korporacyjnego rynku. To także odrzucenie możliwości, aby „nasze subiektywności były konstruowane poza informacjami i praktykami, które nas otaczają"10. Pojawiają się zatem w teorii krytycznej postulaty

7 Z. Kwieciński, Pedagogika i edukacja wobec wyzwania kryzysu i gwałtownej zmiany społecz$n e j$, [w:] Z. Kwieciński, L. Witkowski (red.), Ku pedagogii pogranicza, Toruń 1990, s. 5.

${ }_{8}$ Zob. P. Mikiewicz, Społeczne światy szkót średnich. Od trajektorii marginesu do trajektorii elit, Wrocław 2005.

9 T. Szkudlarek, Pedagogika krytyczna, [w:] Z. Kwieciński, B. Śliwerski (red.), Pedagogika ogólna. Podręcznik akademicki, t. 1, Warszawa 2004, s. 366.

${ }_{10}$ P. McLaren, Life in Schools, New York 1986, za: Z. Melosik, Współczesne amerykańskie spory edukacyjne (między socjologia edukacji a pedagogika postmodernistyczna), Poznań 1994, s. 61. 
działań na rzecz tych, którzy w danej sytuacji są uznawani za pokrzywdzonych i projekt radykalnej naprawy życia społecznego i edukacji, który obejmuje bardzo szeroki zakres oddziaływań - od czynników makrostrukturalnych (struktura społeczna, relacje władzy), poprzez instytucjonalne (szkoła i jej program), po jednostkowe (strategie adaptacji i oporu, konstrukcja podmiotowości w relacjach dominacji). Główne kierunki pożądanych zmian w edukacji związane są z: „polityką różnicy" (wartościowa edukacja powinna dostrzegać i akceptować różnice społeczne zamiast je ujednolicać), „polityką głosu” (skłanianie do wyrażania zróżnicowanych poglądów zamiast narzucania kultury elit i narzucania milczenia mniejszościom) oraz „upełnomocnienia” (kształcenie kompetencji do kierowania własnym życiem w miejsce bierności i podporządkowania). Te trzy elementy nazwane odpowiednio przez amerykańskich teoretyków pedagogiki krytycznej: politics of difference, politics of voice oraz empoverment składają się na podstawę strategii radykalnej edukacji ${ }^{11}$.

Edukacja pozostaje w relacjach z różnymi obszarami życia. Ich uwzględnienie oznacza ostatecznie myślenie o człowieku, społeczeństwie oraz dwustronnych relacjach między nimi. Rozważanie tym samym kondycji edukacji musi prowadzić do rozlicznych jej uwarunkowań, rozmaitych kontekstów - nie zawsze jasnych, jednoznacznych i pewnych. A ewentualne proponowane jej zmiany wymagają określonego sposobu postrzegania jednostki i jej związków ze społeczeństwem. $\mathrm{W}$ tym stanie rzeczy trudne, ale zarazem bardzo potrzebne przedstawianie klarownej wizji dla edukacji, wymaga rozpoznania jej powiązań (nie zawsze są one wbrew pozorom oczywiste) oraz wypracowania odpowiednio do nich adekwatnej strategii, w której nie może się zgubić człowiek. Warto w tym miejscu przywołać spośród różnorodnych dokumentów Biała Księge, akurat po to, by się przekonać, że jeśli ten właśnie dokument Komisji Europejskiej

obstaje przy roli jednostki jako najważniejszego uczestnika społeczeństwa, dzięki autonomii i wiedzy, która pozwoli jej pozytywnie wejść w przyszłość, to tylko po to, aby podkreślić rolę szkoły w tym przeobrażeniu. Szkoła [edukacja - W.S.] musi się przystosować do nowych wymagań, stawać się instrumentem niezastąpionym w rozwoju osobowym i w integracji społecznej każdej jednostki. Dużo się od niej wymaga, gdyż dużo może ona dać' ${ }^{12}$.

W raporcie na temat przyszłości edukacji opracowanym dla UNESCO jego autorzy posługują się żeglarską metaforą, według której edukacja ma być jednocześnie mapą zmiennego i skomplikowanego świata, jak i busolą umożliwiającą

11 T. Szkudlarek, Pedagogika krytyczna, op. cit., s. 370-371.

${ }_{12}$ Biała Księga Kształcenia i Doskonalenia. Nauczanie i uczenie się. Na drodze do uczacego się społeczeństwa, Komisja Europejska, Warszawa 1997. 
poruszanie się po nim ${ }^{13}$. Do tak przedstawianej edukacji można się całkowicie przekonać, co więcej - można wiązać z nią nadzieje - kiedy, wpisując się jeszcze raz w perspektywę morskiej podróży, dopowiemy słowami Zygmunta Baumana, że oto żyjemy „rzuceni na środek morza bez map i kompasu; boje zatonęly albo ich nie widać - mamy tylko dwie możliwości: cieszyć się z zapierających dech wizji nowych odkryć przed nami albo drżeć ze strachu przed zatonięciem” ${ }^{\prime 14}$. Za tym sugestywnym obrazem - jaki tworzą zestawienia obu metafor - kryje się wiara w moc edukacji, szczególnie jeśli prowadzi ona do znalezienia remedium na poczucie zagubienia w otaczającym nas świecie. Symptomatyczny jest pod tym względem niejako powrót do raportu UNESCO tylko po to, by móc skonstatować za J. Delorsem, że wiek XXI budzący zarówno lęk, jak i nadzieję, nakazuje poświęcenie większej uwagi edukacji, rozumianej jako ciągły proces doskonalenia wiedzy i umiejętności, które wyposażą człowieka w zdolność odczytywania świata, jego rozumienia oraz w nim działania ${ }^{15}$.

Moc edukacji (już niekoniecznie zbawcza) nabiera siły, jeśli przywołać znany fragment mówiący o czterech filarach, na których edukacja się wspiera: „Uczyć się, by wiedzieć $[\ldots]$ działać [...] żyć wspólnie [...] i aby być" ${ }^{\prime \prime}$.

Odkrywając znaczenie formuł opierających się na nauce i mądrości (wiedza, działanie, współżycie społeczne, bycie sobą), mających prowadzić ku „edukacji bez granic", uczymy się, że oczywistość wcale nie musi być ewidentna. Przekonujemy się, że aby podjąć decyzje o akceptacji czyichś racji (zalecanych strategii dla rozwoju edukacji), trzeba przede wszystkim wykazać się wysiłkiem poznawczym. Niezbędna jest przy podejmowaniu decyzji o zmianach w edukacji specjalistyczna wiedza. Chciałbym tu dla ilustracji problemu przywołać jedną z opinii B. Śliwerskiego, związanych z oceną demokratyzacji publicznej oświaty. Oto okazuje się, że w prezentacji wzmiankowanego raportu pominięto konieczność przeprowadzenia decentralizacji systemu szkolnego. „Pozwalało to - jak podkreśla Autor - ówczesnej władzy zupełnie pominąć czy zlekceważyć inny, a jakże fundamentalny dla tego projektu zespół czynników politycznych, które rzutują na fundament solidarności społecznej, jakim jest konieczność ożywiania nie tylko procesów gospodarczych, ale i zatroszczenia się o rozwój jednostek w duchu ideału i praktyki demokracji”"17.

${ }^{13}$ Edukacja. Jest w niej ukryty skarb. Raport dla UNESCO Międzynarodowej Komisji do spraw Edukacji dla XXI wieku pod przewodnictwem Jaquesa Delorsa, Warszawa 1998.

14 Z. Bauman, Globalizacja, Warszawa 2000, s. 101.

${ }^{15}$ J. Delors, Uczenie się - nasz ukryty skarb, Raport UNESCO - Edukacja w XXI wieku, „Kultura i Edukacja” 1998, nr 2.

${ }^{16}$ Edukacja. Jest w niej ukryty skarb..., op. cit., s. 85.

${ }_{17}$ B. Śliwerski, Edukacja (w) polityce. Polityka (w) edukacji. Inspiracje do badań polityki oświatowej, Kraków 2015, s. 163-164. 
Uwaga ta prowadzi do problemu, jakim jest kondycja edukacji polskiej, a którego rozstrzygnięcie nie jest ani łatwe, ani jednoznaczne. Lektura różnorodnych dokumentów, śledzenie dyskusji, analiza wyników badań pokazują, że edukacja potrzebuje myślenia i planowania kompleksowego, długofalowego, wariantowego i antycypacyjnego. Specjalnego uzasadnienia nie wymaga też podejmowanie trudu jej przedstawiania poprzez próbę myślowego opanowania rozlicznych praktyk edukacyjnych z intencją ich najlepszego konceptualizowania.

Pozostaje jeszcze zapytać: „kto za tym stoi”? Na pewno twórcy reform zainteresowani zmianami w edukacji, które pasują ideologicznie do założeń jej reformy oraz politycy przyczyniający się do modyfikacji polityki edukacyjnej - bywa, że $\mathrm{w}$ imię pozapedagogicznych ambicji, dogmatów lub uprzedzeń ${ }^{18}$. Ale nie tylko również naukowcy, badacze, uczeni - znajdujący dla siebie swój obszar poznania w edukacji i dla edukacji, i w związku z jego eksploracją oraz eksplikacją ujawniający interesy poznawcze (techniczny, praktyczny i emancypacyjny - w sensie nadawanym im przez Jürgena Habermasa) ${ }^{19}$. Są jeszcze oczywiście nauczyciele, uczniowie i ich rodzice. Dla nich edukacja jest polem, na którym istnieje szansa wspólnego spotkania zwolenników określonej opcji - bez „robienia oka” do wszelkich ofert ideologicznych.

\section{Kwestia wspólnotowości - edukacyjne realia}

W analizach rzeczywistości, której kształt formuje się nieustannie w procesach ścierania się różnorodnych praktyk społecznych; w sposobach przedstawiania jednostki zainteresowanej tworzeniem własnego świata życia poprzez własną praktykę, znajdujemy te obrazujące, iż trafiamy do „świata małych pudełek”, składającego się ze zintegrowanych społeczności - z którym, jak przekonuje M. Marody, współczesne jednostki, mimo że otoczone „spersonalizowanymi społecznościami”, wydają się żyć w stanie permanentnego wyobcowania ${ }^{20}$. O tym zaś, jakie ma znaczenie społeczne ulokowanie jednostki i relacje $\mathrm{z}$ innymi, przekonuje Zygmunt Bauman stwierdzeniem:

W dzisiejszym społeczeństwie wszyscy, czy tego chcemy, czy nie, ustawieni jesteśmy w roli jednostek - aktorów - po których należy się spodziewać samodzielnie podejmowanych i dojrzałych decyzji, i odpowiedzialnych za konsekwencje czynów. Być podmiotem to coś

${ }_{18}$ O polskiej edukacji przełomu wieków i powiązanych z nią dylematami dla władzy oświatowej i reformujących ją sił społecznych zob. B. Śliwerski, Problemy współczesnej edukacji. Dekonstrukcja polityki oświatowej III RP, Warszawa 2009.

19 J. Habermas, Interesy konstytuujace poznanie, „Colloquia Communia” 1985, nr 2.

20 M. Marody, Jednostka po nowoczesności. Perspektywa socjologiczna, Warszawa 2014, s. 262. 
więcej jednak niż być wystawionym na takie oczekiwania i traktowanym, jak gdyby się owe oczekiwania spełniło (lub raczej było zdolnym je spełnić). Być podmiotem to pragnąć odpowiedzialnego i skutecznego działania, dążyć do tego, by posiąść sztukę odpowiedzialnych i skutecznych poczynań - nie szukać ucieczki przed własną odpowiedzialnością - ale też i być w stanie owej odpowiedzialności sprostać. Jednostką się jest, ale podmiotem trzeba się stać ${ }^{21}$.

Za tymi sugestywnymi stwierdzeniami kryje się wiara w działający podmiot, ujmowany w relacjach z innymi, wytwarzający wspólną społeczną rzeczywistość szczególnie jeśli prowadzi ona do znalezienia remedium na poczucie zagubienia w otaczającym nas świecie. Symptomatyczne wydaje się pod tym względem wskazanie na potrzebę angażowania się w „refleksyjność”, aby radzić sobie w tej nowej „nowoczesności”, z którą rozpościera się nowa wolna przestrzeń dająca większą swobodę działania i organizowania własnego życia. W nurcie refleksyjnej jego aranżacji jednostka uwalnia się od krępujących ją więzów. „Wykorzeniona” z dotychczasowej struktury, jaką tworzyły tradycyjne formy społeczne, lokowana jest w nowej rzeczywistości, gdzie jej powiązania i tworzone formy jawią się coraz bardziej jako dowolne i przypadkowe, stanowią niewielką niedogodność i łatwo można się ich pozbyć. Rzec by można, posługując się określeniem Z. Baumana, pojawiają się „wspólnoty wieszakowe” (peg communities) ${ }^{22}$, eksplozywne wspólnoty - „szatniowe” czy „karnawałowe”23. Powstają „wspólnoty”, co do których nie można stwierdzić, czy mamy do czynienia ze wspólnotą, czy ze złudzeniem wspólnoty („nowe plemiona”) ${ }^{24}$. Co więcej,

we współczesnej neoliberalnej rzeczywistości, w której istotą jest walka o sukces, łączenie się w plemiona w coraz większym stopniu ma charakter "przeciwko« - komuś lub czemuś. (...) Zanikają w coraz większym stopniu całożyciowe relacje i koalicje, »braterstwa broni« i więzy. Są one zastępowane przez - powstające niekiedy ad hoc - konfiguracje o charakterze plemiennym (...). Przy tym konfiguracje te mają charakter tymczasowy, czasem są bardzo prowizoryczne ${ }^{25}$.

${ }^{21}$ Z. Bauman, Wieczność w opałach, czyli o wyzwaniach pedagogicznych plynnej nowoczesności, „Teraźniejszość - Człowiek - Edukacja”, Numer Specjalny: Normatywizm - etyczność - zaangażowanie. Wspótczesne dyskusje o praktyczności pedagogiki, 2001, s. 29.

${ }_{22}$ Z. Bauman, Wspólnota. W poszukiwaniu bezpieczeństwa w niepewnym świecie, Kraków 2008, s. 97.

${ }_{23}$ Z. Bauman, Płynna nowoczesność, Kraków 2006, s. 311.

${ }^{24}$ Zob. T. Pilch, Od wspólnoty do osamotnienia..., [w:] J. Piekarski, T. Pilch. W. Theiss, D. Urbaniak-Zając (red.), Edukacja społeczna wobec problemów współczesnego człowieka i społeczeństwa, Łódź 2010, s. 71.

${ }^{25}$ Z. Melosik, Kultura popularna i tożsamość młodzieży. W niewoli władzy i wolności, Kraków 2013, s. 67. 
W odsłanianiu nowego kształtu wspólnot, prowokujących określone dylematy i rozterki, z ich przenikaniem do edukacji musi pojawić się przedsiębiorczy, nastawiony na podejmowanie ryzyka, skuteczny, elastyczny, mobilny, wybierający między konkurencyjnymi strategiami, pozostawiony samemu sobie w realizacji własnego interesu podmiot ${ }^{26}$. Z tak przedstawianym podmiotem wiąże się upodmiotowienie na sposób homo oeconomicus, dokonujące się, jak pisał M. Foucault, wedle nowej „rządomyślności” neoliberalnej: „sposobu, czy mentalności, według której jednostki jednocześnie są rządzone i rządzą samymi sobą. Obowiązującymi terminami rządomyślności nie są już prawa i obowiązki, ale interes, inwestycja i rywalizacja"27. Ciekawą sugestią w odniesieniu do konstytuowania podmiotowości, jaką raczy nas M. Foucault, wydaje się stanowić myśl, iż „nasz świat zamieszkują podmiotowości wyprodukowane mocą wszędobylskich relacji władzy, przybierających różnorakie modalności”28.

Zadaniem otwartym pozostaje nakreślanie wizji, problematyzacja zagadnienia „podmiotowego statusu podmiotów edukacji” ${ }^{29}$. Specyficzną interpretację uzyskują relacje podmiotów edukacji - te przedstawiane zanim jeszcze rzeczywistość się ukaże i zaznaczy w ich doświadczeniu. Jako współkreowane ze świadomością współbycia, współobecności, współdysponowania zakreślonego granicami społecznej identyfikacji podmiotu z innymi uczestnikami życia wspólnotowego, wyodrębnianymi w planach przestrzeni edukacyjnej ${ }^{30}$ dostarczają możliwości dla ponownego przemyśliwania wzajemnego sytuowania się w edukacji (w sieci relacji władzy, „uwikłania kulturowego”) rodziców, nauczycieli, uczniów.

Rozwijając zagadnienie relacji podmiotów edukacji w jego teoretycznej odsłonie wyidealizowanej z rzeczywistości społecznej, sugerować także można, iż wytwarzające się powiązania pomiędzy domem rodzinnym ucznia a szkołą i społecznością lokalną w znaczący sposób sprawiają, że wszyscy korzystają na partnerskim współdziałaniu, dokonującym się w przestrzeni procesu edukacji dzie-

${ }^{26}$ Foucaultowska wersja podmiotu, zob. A. Barry, T. Osborne, N. Rose (red.), Foucault and Political Reason. Liberalism, Neo-liberalism and Rationalities of Government, Chicago 1996.

${ }^{27}$ M. Foucault, The Birth of Biopolitics. Lectures at the Collège de France 1978-1979, Basingstoke 2008, s. 282, cyt. za: K. Starego, Emancypacja - niedokończony projekt edukacji, [w:] M. Szczepska-Pustkowska, M. Lewartowska-Zychowicz, A. Kożyczkowska (red.), Przestrzenie teraźniejszości i ich społeczno-edukacyjne sensy, Toruń 2010, s. 150.

${ }_{28}$ A. Męczkowska, Podmiot i pedagogika. Od oświeceniowej utopii ku pokrytycznej dekonstrukcji, Wrocław 2006, s. 189.

${ }^{29}$ Zapożyczam określenie od A. Męczkowskiej. Por. A. Męczkowska, Podmiot i pedagogika..., op. cit., s. 214.

${ }^{30}$ Zob. J. Modrzewski, Socjologia przestrzeni edukacyjnych, [w:] J. Modrzewski, M.J. Śmiałek, K. Wojnowski (red.), Relacje podmiotów (w) lokalnej przestrzeni edukacyjnej (Inspiracje...), KaliszPoznań 2008. 
$\mathrm{cka}^{31}$. Teoretycznym naświetleniem takowego splotu stała się niewątpliwie teoria pokrywających się sfer wpływów Joyce L. Epstein. Koncepcja znanej w Stanach Zjednoczonych propagatorki dydaktyczno-wychowawczego partnerstwa szkoły i domu przyczynia się w sposób bezprecedensowy do odnowienia problemu współdziałania rodziny, szkoły i społeczności lokalnej, w rozstrzyganie którego zostaje wplecione: rodzicielstwo, komunikacja, wolontariat, nauka domowa, współzarządzanie, współpraca $\mathrm{z}$ gminą ${ }^{32}$. Wykorzystywana w interpretacjach M. Mendel, podejmujących ten problem $\mathrm{z}$ odniesieniem do obecnych polskich realiów edukacyjnych, użyźniła grunt rodzimej pedagogiki.

Szczególny potencjał zawierający się w teorii „pokrywających się sfer”, zgodnie z którą dla skuteczności edukacji dziecka korzystne jest maksymalne zachodzenie na siebie wpływów jego rodziny i szkoły, wydaje się zauważalny w dociekaniu odpowiednich relacji między tymi instytucjami. Ku konkretnemu stanowisku w tej kwestii skłania się Joanna Rutkowiak, która przyjmując za kategorie krytycznego opisu relacji szkoły i domu rodzinnego ucznia kategorie: „udomowienie” i „zadomowienie”, argumentuje ujęcie wskazywanej relacji, uwzględniające „umiarkowane tylko, krytycznie przemyślane uczestnictwo rodziców w życiu szkoły, ich powściągliwość $\mathrm{w}$ byciu wszechobecnymi ludźmi tej instytucji, połączone z zachowaniem społecznej specyfiki życia szkolnego i jego odrębności w stosunku do form i obyczajów domowych"33.

Zauważmy, że wedle tej interpretacji sfery oddziaływania szkoły i domu rodzinnego ucznia wcale nie muszą się pokrywać, a możliwe formy upodobnienia („,udomowienie” i „zadomowienie”) niosą określone konsekwencje, które trudno uznać za rozwojowo korzystne dla wychowanka, na co uczula J. Rutkowiak. Autorka proponuje kontrtezę, wyrażającą się w obronie pozytywnego sensu zachowywania odrębności wychowawczych wpływów szkoły i domu, także zachowywania pewnej odległości w relacjach tych dwóch instytucji. Inspiruje zarazem i tworzy w moim przekonaniu - dobrą okazję do rozpoznawania przestrzeni edukacyjnej, w tym przypadku oczyszczanej z tego, co w rezultacie może sprzyjać kreacji podmiotu i zapobiegać jego wycofywaniu się w swoje zadomowienie.

W optyce niedoceniania sensów: socjalizacji wtórnej, podmiotowości, emancypacyjnego „wychodzenia z domu” ${ }^{34}$ można dostrzec, jak ważne okazują się próby budowania podmiotowych relacji, osiągania kondycji społecznej - powstającej

${ }^{31}$ M. Mendel, Edukacja społeczna. Partnerstwo rodziny, szkoły i gminy w perspektywie amerykańskiej, Toruń 2001, s. 85.

${ }^{32}$ J.L. Epstein, School, Family, and Community Partnerships: Preparing Educators and Improving Schools, Boulder, CO 2001.

${ }^{33}$ J. Rutkowiak, „Udomowienie” $i$ „zadomowienie” jako kategorie krytycznego opisu relacji szkoty i domu rodzinnego ucznia, „Teraźniejszość - Człowiek - Edukacja” 2000, nr 1 (09), s. 22.

${ }^{34}$ J. Rutkowiak, op. cit. 
w przestrzeni kontaktów, pomiędzy ludźmi, nazywanej „wspólnością”35. Widać wyraźnie, jak bardzo liczy się pedagogiczna, kompetentna czujność, by nie zgubić tego, co dziś nas wyjątkowo obchodzi. Podpowiedź, z której w tym miejscu skorzystam, pozbywając się przywileju dostarczenia własnej konkluzji, stanowi myśl M. Mendel, sprowadzona tym razem do problemu miejsca.

Mogłoby to być - pisze Autorka - naprawdę wspólnie wykreowane miejsce, konstrukt wolny od panowania jakiejkolwiek uprzywilejowanej grupy. Szkoła może być bowiem miejscem należącym do wspólnoty postrzeganej w perspektywie międzykulturowości. W niej - tak jak szkolne mury i granice - rozpuszczą się podziały na tych, co tę przestrzeń opanowali i narzucają kształt temu społecznemu konstruktowi, oraz na zdominowanych, którym nie pozostaje nic innego, jak przyjąć go „bez słowa”, w milczeniu, tkwiąc w wymuszonej warunkami, kulturze ciszy ${ }^{36}$.

Pedagogice miejsca wspólnego wydają się służyć znakomicie postulaty edukacji radykalnie humanistycznej. Podążając za Z. Kwiecińskim, pozostaje stwierdzić, że

Pedagogika i edukacja musi zatem zrozumieć możliwość innej, odmiennej swojej roli: funkcji medium między kulturą zastaną a tworzoną, między teraźniejszością a przyszłością, między stronami w konfliktach społecznych, roli oferowania zachowania tożsamości (mimo niestabilności otoczenia społecznego) i systemów wartości, oferowanych do wybo$\mathrm{ru}$, roli uświadamiania jednostkom ich potencjału emancypacyjnego ${ }^{37}$.

W takiej konwencji myślowej podmiotowość relacji w edukacji, kształtowanie świadomości wspólnotowej to materia dociekań pedagogicznych, która wykracza poza ramy teraźniejszości i uczy innego spojrzenia na powszechność. To transparencja „możliwej rzeczywistości” dla nauczyciela, rodzica i ucznia, którzy "pedagogicznie nakierowani” lokują się na „edukacyjnej drodze do wiedzy i umiejętności", wypełniając określone reguły, objęte ich zasięgiem i staraniami. Reguły te przepowiadają rzeczywistość, w której kultura rodziców, ciągle ukryta i raczkująca, w toku interaktywnej wymiany z innymi (kulturą uczniów i „ludzi szkoły”, lokalnych instytucji i grup) rozwinęła się i sprostała w ten sposób dzisiejszemu wyzwaniu, jakim jest uspołecznienie szkoły poprzez aktywizację rodziców - pełnoprawnych członków jej społeczności ${ }^{38}$.

${ }^{35}$ M. Mendel, Pedagogika miejsca wspólnego. Miasto i szkoła, Gdańsk 2017, s. 287.

${ }^{36}$ M. Mendel, Miejsca rodziców w przestrzeni szkoły, [w:] M. Mendel (red.), Pedagogika miejsca, Wrocław 2006, s. 270-271.

37 Z. Kwieciński, Socjopatologia edukacji, Olecko 1995, s. 29.

${ }^{38}$ Ibidem, s. 271. 
Wraz z postulowaną koniecznością wypełnia się niewątpliwie przestrzeń edukacyjna, w której stwierdza się ciągle obecność relacji adaptacji społecznej, poszerza się pole praktyk pedagogicznych - kształtuje się ono pod wpływem humanistycznych idei wychowania antyautorytarnego ${ }^{39}$, przełamujących jednocześnie

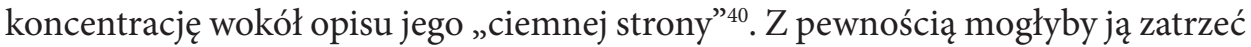
instytucjonalne formy edukacji uczestniczące w stymulowaniu rozwoju jednostki, podejmujące się zadania „polegającego na dostarczeniu przesłanek i potencjału do kształtowania spójnej, twórczej, coraz bardziej autonomicznej i witalnej postawy wobec świata społecznego - postawy kumulującej się w biografię niepowtarzalnego "ja« i jego poczucie »spełnienia« w życiu"41.

Przyjmując tę perspektywę, edukacja, o ile ma stanowić przestrzeń budowania ludzkiej autonomii, indywidualnego kształtowania biografii, przebywania poprzez uczestnictwo w osobowych relacjach wychowawczych, winna tworzyć już w swych własnych ramach realia sfery publicznej, w której centralne miejsce zajmuje dia$\log$ toczący się między różnymi uczestniczącymi w niej podmiotami: uczniami, nauczycielami, rodzicami, środowiskami lokalnymi ${ }^{42}$. Stan realny towarzyszącego mu porozumienia i współdziałania zaświadczać będzie o racjonalności sposobów pozostawania w relacji rodziny, szkoły, gminy, uczniów, konstruowanych splotów bycia razem. Staje się tym samym edukacja istotnym wyzwaniem pedagogicznym, szczególnie nośnym w warunkach demokratyzacji życia społecznego, które aktualnie rozwijamy. Chciałoby się dodać - wyzwaniem pozbawionym kontekstu zawłaszczania jej sensu i funkcjonowania przez interesy polityczno-ekonomiczne i tym samym zaprzeczyć stwierdzeniu, że „edukacja nadal jest biedna, a pedagogika mizerna, ale problem edukacji jest nieustannie przyklejony do uśmiechów polityków, a wybitni ekonomiści poświęcają jego racjonalizacji mnóstwo teoretycznego wysiłku"43.

${ }^{39}$ Zob. B. Śliwerski, Edukacja autorska, Kraków 1996; Z. Melosik, B. Śliwerski (red.), Edukacja alternatywna w XXI wieku, Poznań-Kraków 2010; Z. Kwieciński, (red.), Alternatywy myślenia o/dla edukacji. Wybór tekstów, Warszawa 2000.

${ }^{40}$ Zob. Z. Kwieciński, Tożsamość i rozwój młodzieży a edukacja, „Teraźniejszość - Człowiek Edukacja" 2000, Numer Specjalny; także E. Trempała, Zagrożenia rozwoju człowieka marginalizacja i wykluczeniem w środowiskach lokalnych a pedagogika społeczna, [w:] K. Marzec-Holka (red.), Marginalizacja w problematyce pedagogiki społecznej i praktyce pracy socjalnej, Bydgoszcz 2005.

${ }^{41}$ L. Witkowski, Edukacja i humanistyka. Nowe (Kon)teksty dla nowoczesnych nauczycieli, t. II, Warszawa 2007, s. 216.

42 Ibidem, s. 229.

${ }^{43}$ T. Szkudlarek, Globalizacja, ekonomia i edukacja: o metaforze ludzkiego kapitatu w polityce oświatowej, [w:] E. Malewska, B. Śliwerski (red.), Pedagogika i edukacja wobec nowych wspólnot i różnic w jednoczacej się Europie. Materiały z IV Ogólnopolskiego Zjazdu Pedagogicznego, Kraków 2002, s. 107. 


\section{Pytanie o demokrację - sugestywne podpowiedzi}

Demokracja, jak podnosił John Dewey, jest to „przede wszystkim sposób wspólnotowego życia, zakorzeniony w kulturze i społecznych relacjach codziennego życia”, to „własny sposób osobistego życia”"44.

Przy wybranym sposobie przedstawiania demokracji istotne jest, że w pojęciu demokracji można widzieć kierunek poszukiwań, na linii których uzyskamy lepsze zrozumienie dla bycia razem, wspólnego działania. Samo już zdecydowanie się na kreowanie demokratycznego projektu, który za wartość uznaje współistnienie, upoważnia do formułowania uwag (by od razu nie rzec - wątpliwości) wyraźnie zorientowanych na wskazywanie drogi do porozumienia w klimacie solidarności, współpracy opartej na dialogu, wyborów odnoszących się do dobra wspólnego. Nie bez powodu też w refleksjach rozwijanych przez B. Śliwerskiego o polityczności pedagogiki trafiamy na następujący fragment:

Warto lokować pedagogiczne nadzieje w demokracji ze świadomością tkwiących w tym ustroju potencjałów do autentycznego, obywatelskiego zaangażowania się jednostek i grup społecznych z własnej, nieprzymuszonej woli na rzecz współpracy dla dobra wspólnego czy podporządkowania się tak woli większości i lojalności wobec bliskich, jak i wobec przeciwników politycznych ${ }^{45}$.

Kierunek myślenia „ku społeczeństwu obywatelskiemu” wymaga ciągle czasu, a z nim rozważania poszerzenia zakresu roli i zadań współczesnej edukacji ${ }^{46}$. Wolno oczekiwać optymistycznie, że z wypełnianiem jej treściami wynikającymi z dążeń do demokratyzacji kształcenia, wzrostu podmiotowości i odpowiedzialności wszystkich jej uczestników, także decentralizacji polityki edukacyjnej, wyraźnie wzrośnie podmiotowość rodzącego się społeczeństwa obywatelskiego, demokratyczna relacyjność synchronizowana z kształtowaniem świadomości wspólnotowej.

Dla samej edukacji idzie za tym wyzwanie, które w połączeniu z heurystycznie użytecznymi w jego formułowaniu hasłami demokracji, wspólnoty, sprowadza się do tego, by wspólnota ustanawiana w edukacji, współrealizująca demokrację jako jedną z form organizacji życia, dawała wszystkim uczestnikom możliwość wzmacniania jednostkowej autonomii przy jednoczesnym otwieraniu się na zrzeszanie, dialog i gotowość do współpracy. Ważne zadanie dla edukacji to przygotowanie do wspólnotowości, życia i działania w warunkach „istnienia sieci afektywnych relacji

${ }^{44}$ J. Dewey, Creative Democracy - The Task Before Us. An address given at a dinner in honour of John Dewey, New York 1939.

${ }_{45}$ B. Śliwerski, Edukacja (w) polityce..., op. cit., s. 115.

${ }^{46} \mathrm{~J}$. Muszyńska, Od regionu do lokalności - ku społeczeństwu obywatelskiemu, „Pedagogika Społeczna" 2012, nr 1. 
w obrębie grupy jednostek; relacji, które często krzyżują się i wzmacniają nawzajem $(. . .)^{\text {"47 }}$ oraz występowania „identyfikacji ze wspólnymi wartościami, normami i znaczeniami, a także ze wspólną historią i tożsamością - krótko mówiąc, ze wspólną kulturą" ${ }^{48}$, co powinno złożyć się niejako automatycznie w konstruktywny kształt społeczeństwa - opowiadającego się za demokratyzacją życia, również samej edukacji.

W takim zorientowaniu, wychodząc od gotowości do podjęcia myślowej pracy i współodpowiedzialności za edukację jako dzieło wspólne, droga do demokracji w edukacji, jak i edukacji dla demokracji4 ${ }^{49}$, wydaje się otwartą, niestety, niekoniecznie oczywistą. Jednocześnie, dzięki stawianym drogowskazom, na których są napisane hasła:

- zmiana miejsca i funkcji edukacji w życiu społecznym, a z nią przygotowanie jednostek do krytycznego oglądu otaczającej rzeczywistości oraz kreowanie tej lepszej;

- zmiana relacji między uczestnikami współtworzącymi edukację z tendencją do ich upodmiotowienia ${ }^{50}$,

postulaty reformowania przestrzeni edukacyjnej uzyskują swoje aktualizacje, a przydawany im sens orientujący w stronę edukacji radykalnie humanistycznej ${ }^{51}$, edukacji podmiotowej ${ }^{52}$ stwarza nadzieje na przekraczanie zastanych warunków praktyki współdziałania.

W namyśle nad edukacyjnym doświadczaniem demokracji nie może się obejść bez zwrócenia uwagi na „demokratyczną wspólnotę" odnoszącą się do pojęcia kooperacji ludzi, których łączą cele działania i etyczne zaangażowanie w podejmowane przedsięwzięcia ${ }^{53}$. Ważne też, aby z kształtowaniem obywatela demokratycznej wspólnoty łączyć „wychowanie »w związku z innymi« - oparte na współpracy i zorientowane na wzbogacanie międzyludzkich więzi, kształtujące poczucie od-

${ }^{47}$ A. Etzioni, Wspólnota responsywna: perspektywa komunitariańska, [w:] P. Śpiewak (wybór tekstów), Komunitarianie. Wybór tekstów, przekł. P. Rymarczyk, T. Szubka, Warszawa 2010, s. 190.

${ }^{48}$ Ibidem.

49 Szerzej: Z. Kwieciński, Demokracja w edukacji czy edukacja dla demokracji?, [w:] Z. Kwieciński, Tropy - ślady - próby. Studia i szkice z pedagogii pogranicza, Poznań-Olsztyn 2000.

${ }^{50}$ Zob. I. Nowosad, Wspótpraca nauczycieli z rodzicami i szkoły ze środowiskiem lokalnym, [w:] I. Nowosad, I. Mortag, J. Ondráková (red.), Jakość życia i jakość szkoły, Zielona Góra 2010.

${ }^{51}$ Z. Kwieciński, O edukację i pedagogikę radykalnie humanistyczną, [w:] B. Suchodolski (red.), Alternatywna pedagogika humanistyczna, Wrocław 1990; Z. Kwieciński, Pedagogika i edukacja wobec wyzwania..., op. cit.

${ }_{52}$ T. Lewowicki, Przemiany oświaty, Warszawa 1994; T. Lewowicki, Podmiotowość w edukacji, [w:] W. Pomykało (red.), Encyklopedia pedagogiczna, Warszawa 1993.

${ }^{53}$ J. Dewey, za: A. Męczkowska-Christiansen, Edukacja dla demokracji jako demokracja w edukacji. Wokót podstawowych pojęć, [w:] K. Gawlicz, P. Rudnicki, M. Starnawski, T. Tokarz (red.), Demokracja i edukacja. Dylematy, diagnozy, doświadczenia, Wrocław 2014, s. 20. 
powiedzialności za zamieszkiwany świat", którego zaprzeczeniem jest orientacja na kształtowanie „człowieka masowego" ${ }^{\text {. }}$.

Można też postulować - jak chce S. Shapiro - transformatywny dyskurs edukacyjny, oznaczający promowanie języka i programu reform edukacji, której najważniejszym celem byłoby wychowanie młodzieży w celu stworzenia społecznie sprawiedliwej, społecznie odpowiedzialnej, demokratycznej i solidarnej wspólnoty ${ }^{55}$.

W takim zorientowaniu - bez ideologicznych barier, wychodząc od gotowości do podjęcia myślowej pracy i współodpowiedzialności za edukację jako dzieło wspólne - wkroczenie na drogę urzeczywistniania demokratycznego współdziałania wydaje się oczywiste. Z drogą tą wolno też kojarzyć horyzont interpretacyjny z wyraźnie zarysowaną logiką nadziei i możliwości. Wystarczy dostrzec, że widać na niej - w ogólnym zarysie - pedagoga miejsca wspólnego z przypisanym mu znaczeniem sprzymierzeńca ${ }^{56}$. Bez specjalnego wysiłku intelektualnego możemy sobie już wyobrazić koncepcję działania pedagoga, w której m.in. dostrzega się potencjał tkwiący w osobach, grupach i traktuje się go jak podstawę organizowanych sieci współpracy; przezwycięża przeszkody blokujące wspólność; uczy społeczność politycznego działania, występowania w obronie i na rzecz wspólności ${ }^{57}$.

Można by pokusić się jeszcze o stwierdzenie, że budowanie wspólnoty edukacyjnej w naszej rzeczywistości wymaga „uczenia się sztuki demokracji”" ${ }^{2}$, bardziej zaangażowanego uczestnictwa aniżeli kontestacji. Problem podejmowania działań na rzecz odnowy edukacji ze znaczącym udziałem tych form wspólnoty, które ustrukturowane są demokratycznie i współrealizują demokrację jako jedną z form organizacji życia (na które nadzieje budził już J. Dewey) ${ }^{59}$ pozostaje.

Ostatecznie, „demokratyczny ład społeczny jest dla nas zadaniem edukacyjnym” ${ }^{60}$, a pytanie „Czy w polskiej oświacie jest miejsce na demokrację jako wartość, a zatem na: partycypację, sprawiedliwość, równość, wspólne podejmowanie decyzji, pracę w grupach, współpracę, podział władzy, wzmacnianie

54 Ibidem.

55 S. Shapiro, Zmiana w edukacji i kryzys lewicy. W strone postmodernistycznego dyskursu edukacyjnego, [w:] Z. Kwieciński, L. Witkowski (red.), Spory o edukację. Dylematy i kontrowersje we współczesnych pedagogiach, Warszawa 1993, s. 179.

56 M. Mendel, Pedagogika miejsca wspólnego..., op. cit., s. 350.

57 Ibidem, s. 352.

58 E.J. King, Demokratyzacja szkolnictwa średniego, [w:] A. Mońko-Stanikowa (red.), Oświata $i$ wychowanie w toku przemian, Warszawa 1979.

59 J. Dewey, Die Öffentlichkeit und ihre Probleme, Bodenheim 1996 (wyd. oryg. 1927).

60 Z. Kwieciński, Demokracja jako zadanie edukacyjne i problem dla pedagogiki, [w:] B. Śliwerski (red.), Pedagogika alternatywna - dylematy teorii, Łódź-Kraków 1995. 
ról społecznych, wzajemny szacunek i różnorodność, odmienność?" 61 - wymaga ciągłych analiz (bez pewności uzyskania potwierdzających rozstrzygnięć).

\section{Bibliografia}

Barry A., Osborne T., Rose N. (red.), Foucault and Political Reason. Liberalism, Neo-liberalism and Rationalities of Government, Chicago 1996.

Bauman Z., Globalizacja, Warszawa 2000.

Bauman Z., Płynna nowoczesność, Kraków 2006.

Bauman Z., Wieczność w opałach, czyli o wyzwaniach pedagogicznych płynnej nowoczesności, „Teraźniejszość - Człowiek - Edukacja”, Numer Specjalny: Normatywizm - etyczność - zaangażowanie. Wspótczesne dyskusje o praktyczności pedagogiki, 2001.

Bauman Z., Wspólnota. W poszukiwaniu bezpieczeństwa w niepewnym świecie, Kraków 2008.

Biała Księga Kształcenia i Doskonalenia. Nauczanie i uczenie się. Na drodze do uczącego się społeczeństwa, Komisja Europejska, Warszawa 1997.

Delors J., Uczenie się - nasz ukryty skarb, Raport UNESCO - Edukacja w XXI wieku, „Kultura i Edukacja" 1998, nr 2.

Dewey J., Creative Democracy - The Task Before Us. An address given at a dinner in honour of John Dewey, New York 1939.

Dewey J., Die Öffentlichkeit und ihre Probleme, Bodenheim 1996 (wyd. oryg. 1927).

Edukacja. Jest w niej ukryty skarb. Raport dla UNESCO Międzynarodowej Komisji do spraw Edukacji dla XXI wieku pod przewodnictwem Jaquesa Delorsa, Warszawa 1998.

Epstein J.L., School, Family, and Community Partnerships: Preparing Educators and Improving Schools, Boulder, CO 2001.

Etzioni A., Wspólnota responsywna: perspektywa komunitariańska, [w:] P. Śpiewak (wybór tekstów), Komunitarianie. Wybór tekstów, przekł. P. Rymarczyk, T. Szubka,Warszawa 2010.

Habermas J., Interesy konstytuujące poznanie, „Colloquia Communia” 1985, nr 2.

King E.J., Demokratyzacja szkolnictwa średniego, [w:] A. Mońko- Stanikowa (red.), Oświata i wychowanie w toku przemian, Warszawa 1979.

Konarzewski K., O pewnej sprzeczności w projekcie reformy polskiej oświaty, „Edukacja” 1999, nr 1.

Kwieciński Z., Demokracja jako wyzwanie i zadanie edukacyjne, [w:] Z. Melosik, K. Przyszczypkowski (red.), Wychowanie obywatelskie. Studium teoretyczne, porównawcze i empiryczne, ToruńPoznań 1998.

Kwieciński Z., Demokracja jako zadanie edukacyjne i problem dla pedagogiki, [w:] B. Śliwerski (red.), Pedagogika alternatywna - dylematy teorii, Łódź-Kraków 1995.

Kwieciński Z., Demokracja w edukacji czy edukacja dla demokracji?, [w:] Z. Kwieciński, Tropy - ślady-próby. Studia i szkice z pedagogii pogranicza, Poznań-Olsztyn 2000.

Kwieciński Z., Edukacja jako wartość odzyskiwana wspólnie (Głos w dyskusji o uspołecznieniu szkoły), „Edukacja” 1991, nr 1.

${ }^{61}$ B. Śliwerski, Polska edukacja wobec demokracji jako idei, wartości, ustroju. Konferencja: Edukacja w Polsce: diagnoza, modele, prognozy. Tezy referatów, PAN, Komitet Prognoz „Polska 2000 plus”, Komitet Nauk Pedagogicznych, Warszawa, 23 stycznia 2013. 
Kwieciński Z., O edukację i pedagogikę radykalnie humanistyczną, [w:] B. Suchodolski (red.), Alternatywna pedagogika humanistyczna, Wrocław 1990.

Kwieciński Z., Pedagogika i edukacja wobec wyzwania kryzysu i gwałtownej zmiany społecznej, [w:] Z. Kwieciński, L. Witkowski (red.), Ku pedagogii pogranicza, Toruń 1990.

Kwieciński Z., Socjopatologia edukacji, Olecko 1995.

Kwieciński Z., Tożsamość i rozwój młodzieży a edukacja, „Teraźniejszość - Człowiek - Edukacja” 2000, Numer Specjalny.

Kwieciński Z. (red.), Alternatywy myślenia o/dla edukacji. Wybór tekstów, Warszawa 2000.

Lewowicki T., Podmiotowość w edukacji, [w:] W. Pomykało (red.), Encyklopedia pedagogiczna, Warszawa 1993.

Lewowicki T., Przemiany oświaty, Warszawa 1994.

Lewowicki T., W stronę paradygmatu edukacji podmiotowej, „Edukacja” 1991, nr 1.

Marody M., Jednostka po nowoczesności. Perspektywa socjologiczna, Warszawa 2014.

Melosik Z., Kultura popularna i tożsamość młodzieży. W niewoli władzy i wolności, Kraków 2013.

Melosik Z., Wspólczesne amerykańskie spory edukacyjne (między socjologiq edukacji a pedagogika postmodernistyczna), Poznań 1994.

Melosik Z., Śliwerski B. (red.), Edukacja alternatywna w XXI wieku, Poznań-Kraków 2010.

Mendel M., Edukacja społeczna. Partnerstwo rodziny, szkoły i gminy w perspektywie amerykańskiej, Toruń 2001.

Mendel M., Miejsca rodziców w przestrzeni szkoły, [w:] M. Mendel (red.), Pedagogika miejsca, Wroclaw 2006.

Mendel M., Pedagogika miejsca wspólnego. Miasto i szkoła, Gdańsk 2017.

Męczkowska A., Podmiot i pedagogika. Od oświeceniowej utopii ku pokrytycznej dekonstrukcji, Wrocław 2006.

Męczkowska-Christiansen A., Edukacja dla demokracji jako demokracja w edukacji. Wokół podstawowych pojęć, [w:] K. Gawlicz, P. Rudnicki, M. Starnawski, T. Tokarz (red.), Demokracja i edukacja. Dylematy, diagnozy, doświadczenia, Wrocław 2014.

Mikiewicz P., Społeczne światy szkót średnich. Od trajektorii marginesu do trajektorii elit, Wrocław 2005.

Modrzewski J., Socjologia przestrzeni edukacyjnych, [w:] J. Modrzewski, M.J. Śmiałek, K. Wojnowski (red.), Relacje podmiotów (w) lokalnej przestrzeni edukacyjnej (Inspiracje...), Kalisz-Poznań 2008.

Muszyńska J., Od regionu do lokalności - ku społeczeństwu obywatelskiemu, „Pedagogika Społeczna” 2012, nr 1.

Nowosad I., Wspótpraca nauczycieli z rodzicami i szkoły ze środowiskiem lokalnym, [w:] I. Nowosad, I. Mortag, J. Ondráková (red.), Jakość życia i jakość szkoły, Zielona Góra 2010.

Pilch T., Od wspólnoty do osamotnienia..., [w:] J. Piekarski, T. Pilch. W. Theiss, D. Urbaniak-Zając (red.), Edukacja społeczna wobec problemów współczesnego człowieka i społeczeństwa, Łódź 2010.

Przyszczypkowski K., Edukacja dla demokracji. Strategie zmian a kompetencje obywatelskie, ToruńPoznań 1999.

Rutkowiak J., „Udomowienie” $i$ „zadomowienie” jako kategorie krytycznego opisu relacji szkoły i domu rodzinnego ucznia, „Teraźniejszość - Człowiek - Edukacja” 2000, nr 1 (09).

Shapiro S., Zmiana w edukacji i kryzys lewicy. W stronę postmodernistycznego dyskursu edukacyjnego, [w:] Z. Kwieciński, L. Witkowski (red.), Spory o edukację. Dylematy i kontrowersje we wspótczesnych pedagogiach, Warszawa 1993. 
Starego K., Emancypacja - niedokończony projekt edukacji, [w:] M. Szczepska-Pustkowska, M. Lewartowska-Zychowicz, A. Kożyczkowska (red.), Przestrzenie teraźniejszości i ich społeczno-edukacyjne sensy, Torun 2010.

Szkudlarek T., Globalizacja, ekonomia i edukacja: o metaforze ludzkiego kapitału w polityce oświatowej, [w:] E. Malewska, B. Śliwerski (red.), Pedagogika i edukacja wobec nowych wspólnot i różnic w jednoczacej się Europie. Materiały z IV Ogólnopolskiego Zjazdu Pedagogicznego, Kraków 2002.

Szkudlarek T., Pedagogika krytyczna, [w:] Z. Kwieciński, B. Śliwerski (red.), Pedagogika. Podręcznik akademicki, t. 1, Warszawa 2004.

Śliwerski B., Edukacja autorska, Kraków 1996.

Śliwerski B., Edukacja (w) polityce. Polityka (w) edukacji. Inspiracje do badań polityki oświatowej, Kraków 2015.

Śliwerski B., Pedagogika (w) demokracji, „Przegląd Pedagogiczny” 2014, nr 1.

Śliwerski B., Polska edukacja wobec demokracji jako idei, wartości, ustroju. Konferencja: Edukacja w Polsce: diagnoza, modele, prognozy. Tezy referatów, PAN, Komitet Prognoz „Polska 2000 plus”, Komitet Nauk Pedagogicznych, Warszawa, 23 stycznia 2013.

Śliwerski B., Problemy wspótczesnej edukacji. Dekonstrukcja polityki oświatowej III RP, Warszawa 2009.

Trempała E., Zagrożenia rozwoju człowieka marginalizacja i wykluczeniem $w$ środowiskach lokalnych a pedagogika społeczna, [w:] K. Marzec-Holka (red.), Marginalizacja w problematyce pedagogiki społecznej i praktyce pracy socjalnej, Bydgoszcz 2005.

Witkowski L., Edukacja i humanistyka. Nowe (Kon)teksty dla nowoczesnych nauczycieli, t. II, Warszawa 2007.

Witkowski L., Edukacja wobec sporów o (po)nowoczesność, Warszawa 1998. 